\title{
HUBUNGAN PREEKLAMPSIA DALAM KEHAMILAN DENGAN KEJADIAN BBLR DI RSUD JENDERAL AHMAD YANI KOTA METRO TAHUN 2011
}

\author{
Sri Lestariningsih*Artha Budi Susila Duarsa**
}

\section{ABSTRAK}

Masalah bayi berat lahir rendah (BBLR) sampai saat ini masih merupakan penyebab utama morbiditas dan mortalitas perinatal. Preeklampsia merupakan salah satu faktor risiko terjadinya pertumbuhan janin yang lambat, BBLR, dismaturitas dan prematuritas janin dan bahkan terjadi intra uterine fetal death (IUFD). Tujuan penelitian ini adalah untuk mengetahui hubungan preeklampsia dalam kehamilan dengan kejadian BBLR setelah mengontrol variabel anemia, usia $\mathrm{ibu}$, jarak persalinan, paritas, pendidikan, pekerjaan, kehamilan prematur, dan riwayat abortus. Desain penelitian ini adalah Case Control dengan menggunakan data ibu yang melahirkan di RSUD Jenderal Ahmad Yani. Populasi adalah ibu yang melahirkan dalam kurun waktu tahun 2011. Sampel berjumlah 186 terdiri dari 93 kasus dan 93 kontrol. Penarikan sampel kelompok kontrol secara Systematic Random Sampling. Analisis bivariat menggunakan uji Chi Square, sedangkan analisis multivariat dengan menggunakan regresi logistik ganda. Hasil penelitian menunjukkan ada hubungan yang signifikan antara preeklampsia dengan kejadian $\mathrm{BBLR}$ (nilai $\mathrm{p}=0,000, \mathrm{OR}=10,11$ ), ibu hamil dengan preeklampsia kemungkinan berisiko 12,69 kali lebih besar untuk melahirkan bayi BBLR dibandingkan ibu hamil yang tidak preeklampsia setelah dikontrol variabel riwayat abortus, paritas, dan pendidikan ibu. Saran perlunya melaksanakan praktek antenatal yang bermanfaat: Sedikitnya harus 4 kali datang berkunjung dengan memperhatikan kelengkapan pelayanan antenatal dengan standar pelayanan " $14 \mathrm{~T}$ ".

\section{Kata kunci : BBLR, preeklampsia}

\section{ABSTRACT}

The background factors that cause newborn baby death were very complex. One of them was low newborn baby weight. It was still the main factor causing prenatal morbidity and mortality nowadays. Preeclampsia was one of the factors causing risk of tardy fetus growth, low newborn baby weight, immaturity and prematurity fetus, and even intra uterine fetal death (IUFD). This research aim was to know the relationship between preeclampsia of pregnancy and low newborn baby weight after controlling some variables such as anemia, age, children birth distance, parity, education, occupation, premature pregnancy, and history of abortion. The researcher used case control design in this thesis by using data of mothers who gave birth in Jenderal Ahmad Yani Regional Public Health Hospital Metro City. The population was taken from the data of mothers who gave birth during 2011. Samples were 186 consisting of 93 cases samples and 93 controls samples. The researcher used systematic random sampling to take the sample of control group. The researcher user chi square in bivariate analysis and binary logistic regression in multivariat analysis. The result shows there was a signifikan relationship between preeklampsia with low newborn baby weight (with score $p=0,000, O R=10,11$ ). The multivariate analysis shows that pregnancy woman with preeclampsia has 12,69 times bigger risk to give birth than pregnancy woman who doesn't have preeclampsia after being controlled her history of abortion, parity, and education. The researcher suggests a pregnancy woman to have beneficial antenatal practice: at least 4 times coming to visit by paying attention to antenatal service completeness with "14T" service standard.

\section{Key Words : Low Newborn Baby Weight, preeclampsia}

\section{Pendahuluan}

Penyebab kematian bayi menurut Word

Health Organization (WHO) salah satunya adalah karena bayi berat lahir rendah (BBLR) (Badan Pusat Statistik, 2008)'. Masalah BBLR sampai saat ini masih merupakan penyebab utama morbiditas dan mortalitas perinatal. Setiap tahun di dunia diperkirakan lahir sekitar 20 juta bayi berat lahir rendah. Dalam laporan WHO yang dikutip dari State of the world's mother 2007 (data tahun 2000-2003) dikemukakan bahwa $27 \%$ kematian neonatus disebabkan oleh BBLR (Ivones, J., 2012).

\footnotetext{
* Staf Program Studi Kebidanan Metro Poltekkes Kemenkes Tanjungkarang, Jl. Brigjend SutiyosoPage

No 1 Kota Metro Po Box 107 Kode Pos 34111 (e-mail : lestariningsihs@yahoo.co.id)

** Kabag. IKM Fakultas Kedokteran Universitas YARSI, Menara YARSI Lt. 5, Jl. Letjen Suprapto

Cempaka Putih, Jakarta Pusat (e-mail : arthabudi@gmail.com) 
Menurut Depkes RI (2008) ${ }^{3}$, penyebab kematian neonatal terbesar adalah BBLR yaitu sebesar $30,3 \%$. Secara statistik menunjukkan $90 \%$ kejadian BBLR didapatkan di negara berkembang dan angka kematiannya 35 kali lebih tinggi dibanding pada bayi dengan berat lahir lebih dari 2500 gram.

BBLR diseluruh dunia mencapai lebih dari 20 juta bayi $(15,5 \%)$ dari seluruh kelahiran, dan $95,6 \%$ diantaranya merupakan bayi yang dilahirkan di negara-negara sedang berkembang. Proporsi BBLR di Indonesia diketahui berdasarkan estimasi. Jika proporsi ibu hamil yang akan melahirkan bayi adalah $2,5 \%$ dari total penduduk, maka setiap tahun diperkirakan 355.000 sampai 710.000 dari 5 juta bayi lahir dengan kondisi BBLR (Depkes R.I., $2000)^{4}$.

Berdasarkan Riskesdas 2010, kejadian BBLR di Provinsi Lampung sebesar 9\% dan sedikit lebih baik dari angka nasional yaitu $11,1 \%$. Kasus BBLR di Kabupaten Lampung Tengah tahun 2009 sebesar $31,03 \%$ (18 kasus) (Dinas Kesehatan Kabupaten Lampung Tengah, 2010) ${ }^{6}$, sedangkan di Kabupaten Lampung Timur, BBLR sebesar 31 kasus $(29,5 \%)$ pada tahun 2009 (Dinas Kesehatan Kabupaten Lampung Timur, 2010) ${ }^{7}$. Kasus BBLR di Lampung Tengah dan Lampung Timur lebih rendah dari kasus BBLR di Kota Metro. Kasus kematian BBLR dalam tiga tahun terakhir yaitu tahun 20082010 merupakan penyebab terbesar kasus kematian bayi di Kota Metro, yaitu pada tahun 2008 sebesar $54 \%$, pada tahun 2009 sebesar $37,9 \%$ dan pada tahun 2010 sebesar 67\% (Dinkes Kota Metro, 2011)

Komplikasi langsung yang dapat terjadi pada BBLR antara lain: hipotermia, hipoglikemia, gangguan cairan dan elektrolit, hiperbilirubinemia, sindroma gawat nafas, paten duktus arteriosus, Infeksi, perdarahan intraventrikuler, apnea of prematurity, anemia (Depkes R.I., 1993) ${ }^{9}$.

Berbagai faktor etiologi BBLR menurut Manuaba (1998) ${ }^{10}$, yaitu faktor ibu (gizi kurang saat hamil, anemia, umur ibu kurang dari 20 tahun atau lebih dari 35 tahun, jarak hamil dan bersalin terlalu dekat, penyakit menahun ibu, faktor pekerja yang terlalu berat), faktor kehamilan (hamil dengan hidramnion, hamil ganda, perdarahan antepartum, komplikasi hamil), faktor janin (cacat bawaan, infeksi dalam rahim). Menurut Depkes (1993), faktor ibu BBLR (trauma fisik dan psikologik, riwayat abortus sebelumnya, nefritis akut, diabetes melitus, paritas lebih dari 4 , pendidikan ibu, ibu yang perokok, peminum alkohol, pecandu narkotik), faktor lingkungan (tempat tinggal di dataran tinggi, radiasi, zat-zat racun).
Preeklampsia berperan dalam kematian intra-uterin dan mortalitas perinatal. Preeklampsia merupakan salah satu faktor risiko terjadinya pertumbuhan janin yang lambat, BBLR, dismaturitas dan prematuritas janin dan bahkan terjadi intra uterine fetal death (IUFD). Ibu yang menderita preeklampsia akan mengalami disfungsi vaskuler plasenta, yang dapat menyebabkan aliran darah ke plasenta terganggu, sehingga kebutuhan janin akan nutrisi dan oksigen tidak terpenuhi secara optimal. Keadaan tersebut mengakibatkan pertumbuhan janin terlambat (Prawirohardjo, 1992).

Penelitian yang dilakukan oleh Wahyuni $(2005)^{12}$ menunjukkan bahwa terdapat hubungan antara preeklampsia berat pada ibu hamil terhadap kejadian bayi berat lahir rendah $(p=0,045)$. Demikian pula kesimpulan hasil penelitian Kurniawati $(2010)^{13}$, ada hubungan yang signifikan antara preeklampsia dengan kelahiran berat bayi lahir. Menurut penelitian Abbas dan Dessyani $\mathbf{H}^{14}$ terdapat hubungan antara preeklampsia/ eklampsia dengan BBLR di RSUD Dr. Moewardi Surakarta Tahun 2010. Berdasarkan hasil penelitian-penelitian tersebut menunjukkan bahwa preeklampsia merupakan faktor risiko terjadinya kelahiran BBLR.

Berdasarkan pra survey di RSUD Jend. Ahmad Yani Kota Metro, terjadi peningkatan angka kejadian BBLR, pada tahun 2009 yaitu $20,06 \%$; meningkat menjadi $23,62 \%$ (2010), serta terjadi peningkatan kejadian preeklampsia, pada tahun 2009 terdapat 88 kasus preeklampsia $(11,11 \%)$ mengalami peningkatan pada tahun 2010 sebanyak 108 kasus $(13,92 \%)$ (Medikal Record R.SUD Jend. Ahmad Yani, 2010) ${ }^{15}$. Penelitian ini untuk mengetahui hubungan antara preeklampsia dalam kehamilan dengan kejadian BBLR pada ibu post partum setelah mengontrol variabel anemia, usia ibu, jarak persalinan, paritas, pendidikan, pekerjaan, kehamilan prematur, dan riwayat abortus di RSUD Jend. Ahmad Yani Kota Metro tahun 2011.

\section{Metode}

Penelitian ini merupakan penelitian analitik observasional dengan desain case control studi. Besar sampel berdasarkan penelitian terdahulu (Sistiarani C, 2008) ${ }^{16}$ menggunakan rumus Lameshow (1997) ${ }^{17}$ yaitu:

$$
n=\frac{\left\{Z_{1-\alpha z 2}\left[\sqrt{\left[P_{2}^{*}\left(1-P_{2}^{*}\right)\right]}\right]+Z_{*-1} \sqrt{\left.\left[P_{1}^{*} *\left(1-P_{1}^{*}\right)+P_{2}^{* *\left(1-P_{2}^{*}\right.}\right)\right]}\right\}^{2}}{\left(P_{1}^{*}-P_{2}^{*}\right)^{2}}
$$

Didapat jumlah sampel minimum kasus sebanyak 71, maka sebanyak 93 kasus BBLR di 
RSUD Jend. A.Yani diambil sebagai kasus, dan 93 tidak BBLR sebagai kontrol diambil secara Systematic Random Sampling. Data penelitian ini diambil dari buku register dan M.R. (medical record) menggunakan check list. Analisis dilakukan secara bertahap yaitu: analisis univariat, bivariat, multivariat dengan menggunakan uji regresi logistik ganda.

Hasil Dan Pembahasan

Tabel 1 : Hubungan Variabel Preeklampsia dan Variabel Kovariat dengan Kejadian BBLR

\begin{tabular}{|c|c|c|c|c|}
\hline \multirow{2}{*}{ Faktor Risiko } & Kasus & Kontrol & \multirow{2}{*}{$\begin{array}{c}\text { Nilai } \\
\mathrm{p}\end{array}$} & \multirow{2}{*}{$\begin{array}{c}\text { OR } \\
95 \% \mathrm{CI}\end{array}$} \\
\hline & $\%$ & $\%$ & & \\
\hline Preeklampsia: & & & \multirow{3}{*}{0,000} & 10,118 \\
\hline $\mathrm{Ya} \quad \mathrm{Y}$ & 45,2 & 7,5 & & $\cdots$ \\
\hline Tidak & 54,8 & 92,5 & & $\times$ \\
\hline Anemia: & & & \multirow{2}{*}{1,000} & \multirow{2}{*}{$\begin{array}{r}0,957 \\
(0,534 \\
1,715)\end{array}$} \\
\hline $\begin{array}{l}\text { Ya } \\
\text { Tidak : }\end{array}$ & $\begin{array}{l}58,1 \\
41,9\end{array}$ & $\begin{array}{l}59,1 \\
40,9\end{array}$ & & \\
\hline Usia ibu: & & & \multirow{3}{*}{0,084} & \multirow{3}{*}{$\begin{array}{c}1,816 \\
(0,973- \\
3,390)\end{array}$} \\
\hline Berisiko & 38,7 & 25,8 & & \\
\hline Kurang berisiko & 61,3 & 74,2 & & \\
\hline $\begin{array}{l}\text { Jarak } \\
\text { persalinan: }\end{array}$ & & & & 1,067 \\
\hline Berisiko & 21,5 & 20,4 & \multirow[t]{2}{*}{1,000} & \multirow{2}{*}{$\begin{array}{l}(0,527- \\
2,162)\end{array}$} \\
\hline Kurang berisiko & 78,5 & 79,6 & & \\
\hline Paritas: & & & \multirow{3}{*}{0,053} & \multirow{3}{*}{$\begin{array}{c}0,321 \\
(0,110 \\
0,9305\end{array}$} \\
\hline Berisiko & 5,4 & 15,1 & & \\
\hline Kurang berisiko & 94,6 & 84,9 & & \\
\hline Pendidikan: & & & \multirow{3}{*}{0,000} & \multirow{3}{*}{$\begin{array}{c}4,003 \\
(2,175- \\
7,367)\end{array}$} \\
\hline Rendah . & 65,6 & 32,3 & & \\
\hline Tinggi & 34,4 & 67,7 & & \\
\hline Pekerjaan: & & & \multirow{3}{*}{0,016} & \multirow{3}{*}{$\begin{array}{c}0,365 \\
(0,16- \\
0,795)\end{array}$} \\
\hline Bekerja & 11,8 & 26,9 & & \\
\hline Tidak bekerja & 88,2 & 73,1 & & \\
\hline Kehamilan & & & & \multirow[b]{2}{*}{0,482} \\
\hline prematur: & & & & \\
\hline Prematur & 25,8 & 41,9 & & \multirow{2}{*}{$\begin{array}{c}(0,259 \\
0,896)\end{array}$} \\
\hline Aterm. & 74,2 & 58,1 & 0,030 & \\
\hline Riwayat & & & & 2,761 \\
\hline Abortus: & & & \multirow{3}{*}{0,012} & \multirow{3}{*}{$\begin{array}{r}(1,300- \\
5,867)\end{array}$} \\
\hline $\mathrm{Ya}$ & 29,0 & 12,9 & & \\
\hline Tidak & 71,0 & 87,1 & & \\
\hline
\end{tabular}

Tabel 2 : Model Akhir Hubungan Preeklampsia dalam Kehamilan dengan Kejadian BBLR

\begin{tabular}{lcccc}
\hline \multicolumn{1}{c}{ Variabel } & $\begin{array}{c}\text { Nilai } \\
\mathbf{p}\end{array}$ & OR & $\mathbf{9 5 \%} \mathbf{C I}$ \\
\hline $\begin{array}{l}\text { Preeklampsia } \\
\text { Riwayat } \\
\text { Abortus }\end{array}$ & 0,000 & 12,693 & 4,593 & $-35,076$ \\
Paritas & 0,181 & 1,987 & 0,726 & $-5,434$ \\
Pendidikan & 0,001 & 0,082 & 0,020 & $-0,341$ \\
\hline
\end{tabular}

\section{Preeklampsia}

Pada kelompok BBLR sebesar 45,2\% dilahirkan dari ibu dengan preeklampsia dan terdapat $7,5 \%$ tidak BBLR dilahirkan dari ibu dengan preeklampsia. Hubungan preeklampsia dalam kehamilan dengan kejadian BBLR secara statistik terbukti signifikan $(\mathrm{p}=0,000)$ dengan $\mathrm{OR}=10,118(95 \% \mathrm{CI}: 4,231-24,196)$, artinya bahwa kemungkinan risiko melahirkan BBLR pada responden dengan preeklampsia adalah 10,118 kali lebih besar dibandingkan pada responden yang tidak preeklampsia.

Penelitian ini sejalan dengan penelitian yang dilakukan oleh Kurniawati ${ }^{13}$, yang menyimpulkan ada hubungan yang signifikan antara preeklampsia dengan kelahiran BBLR di RSUD Sragen tahun 2010. Peluang terjadinya kelahiran BBLR lebih tinggi 3,25 kali daripada tanpa preeklampsia. Juga sejalan dengan penelitian yang dilakukan oleh Wahyuni $\mathrm{dkk}^{12}$, hasil uji statistik tentang hubungan preeklampsia berat pada ibu hamil terhadap BBLR di RSUP Dr.Sardjito Yogyakarta periode tahun 2005 yang menunjukkan bahwa terdapat hubungan antara preeklampsia berat pada ibu hamil terhadap kejadian BBLR.

Pada model akhir terdapat 3 variabel counfounder dengan nilai $\mathrm{OR}=12,693(95 \% \mathrm{CI}$ : 4,593-35,076, artinya bahwa ibu dengan preeklampsia dalam kehamilan kemungkinan berisiko 12,693 kali lebih besar untuk melahirkan BBLR dibandingkan dengan ibu yang tidak preeklampsia setelah dikontrol variabel pendidikan, riwayat abortus, dan paritas.

Vasospasme menyebabkan terjadinya konstriksi vaskular pada berbagai organ termasuk plasenta. Resistensi aliran darah karena konstriksi vaskular akan menyebabkan hipertensi arterial pada plasenta. Menurunnya aliran darah ke plasenta menyebabkan gangguan fungsi plasenta sehingga 
terjadi gangguan pertumbuhan janin (Cunningham, $2005)^{18}$. Dengan menurunnya aliran darah ke plasenta mengakibatkan gangguan fungsi plasenta, sedangkan fungsi plasenta adalah untuk menyalurkan asupan oksigen dan asupan gizi dari ibu ke janin. Jika asupan gizi dan asupan oksigen bagi janin terganggu maka dapat mengakibatkan gangguan pertumbuhan janin sehingga berat badan janin yang dilahirkan rendah. Preeklampsia juga dapat menaikkan tonus uterus dan kepekaan terhadap rangsangan sehingga terjadi partus prematurus (Wiknjosastro, 2005) ${ }^{19}$.

\section{Anemia}

Pada kelompok BBLR, 58,1\% dilahirkan dari ibu yang mengalami anemia, sedangkan pada kelompok tidak BBLR 59,1\% dilahirkan dari ibu yang anemia. Hasil uji statistik bivariat (nilai $\mathrm{p}=1,000$ ) menunjukkan bahwa hubungan antara anemia dengan kejadian BBLR tidak signifikan secara statitistik. Hasil penelitian ini sejalan dengan penelitian yang dilakukan Islamiyati, dkk $(2010)^{20}$ yang menyimpulkan bahwa tidak terdapat hubungan antara anemia ibu hamil dengan kejadian $\operatorname{BBLR}(\mathrm{p}=0,148)$.

Zat mikronutrien (selain seng, folat, tembaga, vitamin A, vitamin E serta zat besi) seperti glukosa dan asam amino merupakan zat nutrisi dominan yang mempengaruhi pertumbuhan janin. Dengan suplai glukosa yang baik akan meningkatkan insulin yang memberikan dampak pada IGF-2 sehingga meningkatkan invasi trofoblast, meningkatkan ukuran plasenta, meningkatkan nutrisi plasenta ke janin sehingga meningkatkan pertumbuhan janin yang normal sesuai usia kehamilan (Charles, 2007 dalam Islamiyati $\mathrm{dkk}, 2010)^{20}$. Glukosa diperoleh banyak dari karbohidrat, protein dan lemak, maka konsumsi karbohidrat, protein serta lemak yang cukup mampu menunjang pertumbuhan janin dalam kandungan. Dapat disimpulkan bila kekurangan zat besi tidak disertai dengan kekurangan zat mikronutrien seperti seng, tembaga, vitamin A dan vitamin $\mathrm{E}$, rendahnya pertumbuhan bayi dalam kandungan kemungkinan tidak terjadi.

Kondisi terpengaruhnya pertumbuhan janin lebih potensial terjadi pada kondisi anemia yang mengalami infeksi dan oleh kondisi anemia berat karena terjadinya mekanisme chronic hypoxia sehingga terjadi penurunan sirkulasi oksigen ke janin secara signifikan (Charles, 2007 dalam Islamiyati $\mathrm{dkk}, 2010)^{20}$.

\section{Usia Ibu}

Responden dengan usia berisiko pada kelompok BBLR terdapat 38,7\%, lebih banyak dibandingkan pada kelompok tidak BBLR yaitu $25,8 \%$, namun pada uji statistik tidak menunjukkan hasil yang signifikan secara statistik (nilai $\mathrm{p}=0,084$ ). Hasil penelitian ini tidak dapat mendukung penelitian sebelumnya, yaitu penelitian yang dilakukan oleh Sistiarani $(2008)^{17}$ menyebutkan bahwa ibu bersalin dengan usia berisiko (umur $<20$ tahun atau $>35$ tahun) mempunyai peluang melahirkan bayi dengan BBLR sebesar 4-5 kali dibandingkan ibu bersalin dengan usia tidak berisiko.

\section{Jarak Persalinan}

Pada uji statistik jarak persalinan dengan kejadian BBLR tidak menunjukkan hasil yang signifikan (nilai $\mathrm{p}=1,000$ ).

Hasil penelitian ini tidak sejalan dengan penelitian yang dilakukan oleh Sistiarani (2008) yang menunjukkan bahwa jarak kelahiran berisiko terhadap kejadian BBLR dengan nilai $\mathrm{p}=0,004$ $(\mathrm{OR}=5,11,95 \% \mathrm{CI}: 1,6-16,18)$.

\section{Paritas}

Ibu yang melahirkan BBLR sebanyak 5,4\% pada ibu dengan paritas beresiko. Hasil uji statistik (nilai $\mathrm{p}=0,053$ ) menunjukkan secara statistik hubungan paritas dengan kejadian BBLR tidak ada hubungan. Hasil multivariat didapatkan hasil nilai $p=0,001$, artinya ada hubungan yang bermakna secara statistik antara paritas dengan kejadian BBLR dan pada reduksi analisis penilaian counfounding selisih OR yaitu $23,44 \%(>10 \%)$ yang berarti bahwa paritas merupakan variabel counfounding, dengan $\mathrm{OR}=0,08$ (95\% CI: 0,020-0,341). Sebanyak 94,6\% BBLR dilahirkan dari ibu dengan paritas kurang berisiko, hal ini dimungkinkan karena faktor-faktor risiko terjadinya BBLR sangat kompleks, bukan hanya dipengaruhi oleh faktor paritas saja.

\section{Pendidikan}

Ibu yang melahirkan BBLR pada ibu yang berpendidikan rendah lebih besar yaitu $65,6 \%$ dibandingkan ibu yang melahirkan tidak BBLR dengan pendidikan rendah yaitu $32,3 \%$. Hasil uji bivariat hubungan pendidikan ibu dengan kejadian BBLR secara statistik terbukti signifikan (nilai $\mathrm{p}=0,000)$. Hasil multivariat menunjukkan pendidikan merupakan variabel counfounding, 
dengan $\mathrm{OR}=5,20 \quad(95 \% \quad \mathrm{CI}: 2,50-10,82)$ artinya kemungkinan risiko melahirkan BBLR pada responden dengan pendidikan rendah adalah 5,29 kali lebih besar dibandingkan pada responden dengan pendidikan tinggi.

Hasil penelitian ini sejalan dengan hasil uji statistik penelitian yang dilakukan oleh Apriyanti $(2009)^{2.1}$ menunjukkan ada hubungan yang bermakna antara pendidikan ibu dengan kejadian BBLR (p value $=0,002$ ).

Menurut Green dalam Notoatmodjo $(2003)^{22}$ pendidikan ibu merupakan salah satu faktor penguat yang mempengaruhi seseorang berperilaku. Tingkat pendidikan merupakan faktor yang mendasari pengambilan keputusan. Pendidikan menentukan kemampuan menerima dan mengembangkan pengetahuan dan teknologi. Semakin tinggi pendidikan ibu akan semakin mampu mengambil keputusan bahwa pelayanan kesehatan selama hamil dapat mencegah gangguan sedini mungkin bagi ibu dan janinnya. Pendidikan juga sangat erat kaitannya dengan tingkat pengetahuan ibu tentang perawatan kehamilan dan gizi selama masa kehamilan.

\section{Pekerjaan}

Ibu yang bekerja 11,8\% melahirkan BBLR, dan $26,9 \%$ tidak BBLR. Pada hasil uji bivariat hubungan pekerjaan ibu dengan kejadian BBLR secara statistik terbukti signifikan (nilai $\mathrm{p}=0,016$ ) dengan $\mathrm{OR}=0,36 \quad(95 \%$ CI: $0,16-0,79)$. Hasil penelitian ini sejalan dengan penelitian yang dilakukan oleh Widiyastuti $(2009)^{23}$ didapatkan pekerjaan ibu mempunyai hubungan yang bermakna dengan kejadian BBLR dengan $\mathrm{p}$ value $=0,03$, $\mathrm{OR}=3,47$. Sebanyak $88,2 \%$ ibu yang tidak bekerja melahirkan BBLR, hal ini dimungkinkan karena secara umum ibu yang bekerja akan menunjang ekonomi keluarga, dibandingkan ibu yang tidak bekerja, dimana pada tingkat ekonomi yang sedang atau ekonomi tinggi akan mempunyai intake makanan yang lebih baik secara kualitas maupun secara kuantitas, yang akan menunjang status gizi baik pada ibu hamil tersebut dibandingkan pada ibu hamil dengan tingkat ekonomi rendah. Faktor sosial ekonomi berperan dalam meningkatkan risiko kejadian. BBLR. Beberapa alasan diantaranya adalah kesulitan dalam pemenuhan kebutuhan kalori dan kebutuhan zat-zat gizi lainnya, kesulitan dalam mendapatkan pemeriksaan kehamilan secara teratur.

Responden yang bekerja tidak mengalami stres yang berat dalam melaksanakan pekerjaannya, dan ibu mempunyai kesempatan untuk istirahat di siang hari, dan cuti pada kehamilan serta persalinan. Juga ibu yang bekerja lebih banyak menerima informasi tentang kesehatan baik dari temantemannya maupun dari media cetak dan media elektronik.

\section{Kehamilan Prematur}

Hubungan kehamilan prematur dengan kejadian BBLR secara statistik terbukti signifikan (nilai $\mathrm{p}=0,030)$ dengan $\mathrm{OR}=0,482 \quad(95 \% \mathrm{CI}$ : $0,259-0,896)$. Hal ini dimungkinkan karena sebanyak $74,2 \%$ BBLR dilahirkan pada ibu dengan kehamilan aterm, lebih banyak dari ibu dengan kehamilan prematur yaitu $25,8 \%$ melahirkan BBLR.

Bayi yang dilahirkan dari ibu dengan kehamilan aterm tetapi berat lahir kurang dari 2500 gram ini pertumbuhannya kurang untuk masa gestasi disebut kecil untuk masa kehamilan (KMK). Penyebab hambatan pertumbuhan intrauterin dipengaruhi oleh berbagai macam faktor kompleks, seperti: faktor maternal, faktor janin, faktor plasenta.

\section{Riwayat Abortus}

Ibu yang mempunyai riwayat abortus $29,0 \%$ melahirkan bayi BBLR, sedangkan $12,9 \%$ tidak melahirkan bayi BBLR. Hubungan riwayat abortus dengan kejadian BBLR secara statistik signifikan (nilai $\mathrm{p}=0,012$ ). Kejadian BBLR pada ibu yang mempunyai riwayat abortus mempunyai peluang risiko melahirkan BBLR 1,79 kali lebih besar dibandingkan pada responden yang tidak mempunyai riwayat abortus.

Menurut Saraswati, ibu hamil yang pernah melahirkan bayi lahir mati mempunyai risiko sebesar 2,83 kali lebih besar untuk melahirkan bayi BBLR dibanding ibu yang tidak pernah melahirkan bayi lahir mati, juga menemukan bahwa ibu yang pernah mengalami keguguran mempunyai risiko 3,08 kali lebih besar untuk melahirkan bayi BBLR dibandingkan dengan ibu yang tidak pernah mengalami keguguran (Simarmata, 2010) ${ }^{24}$.

\section{Kesimpulan dan Saran}

Variabel yang berhubungan dengan kejadian BBLR adalah preeklampsia, pendidikan, pekerjaan, kehamilan prematur, dan riwayat abortus.

Ibu hamil dengan preeklampsia kemungkinan berisiko 12,69 kali lebih besar untuk melahirkan bayi BBLR dibandingkan ibu hamil yang tidak preeklampsia setelah dikontrol variabel pendidikan, riwayat abortus dan paritas.

Diharapkan pada petugas kesehatan untuk 
melaksanakan praktek antenatal yang bermanfaat: Sedikitnya harus 4 kali datang berkunjung dengan memperhatikan kelengkapan pelayanan antenatal dengan standar pelayanan " $14 T$ ".

Memberikan informasi tentang faktor-faktor risiko BBLR pada ibu hamil melalui konseling maupun media seperti leaflet, poster.
Cara penyampaian pesan-pesan kesehatan perlu mempertimbangkan tingkat pendidikan ibu hamil, dengan memakai bahasa yang sederhana atau dengan menterjemahkan ke bahasa daerah agar lebih mudah dimengerti.

\section{Daftar Pustaka}

1. Badan Pusat Statistik (BPS). Survei Sosial Ekonomi Nasional (SUSENAS) Jakarta; 2008.

2. Ivones, J. Pengalaman ibu dengan bayi BBLR yang dirawat di inkubator. http://nezfine.wordpress.com/2012/02/02/peng alaman-ibu-dengan-bayi-bblr-yang-dirawat-diinkubator/;2012.

3. Depkes. R.I. Pedoman Umum Pertolongan Persalinan Normal. Departemen Kesehatan RI, Jakarta; 2008.

4. Depkes R.I. Program Perbaikan Gizi Menuju Indonesia Sehat 2010. Direktorat Bina Gizi Masyarakat, Departemen Kesehatan RI, Jakarta; 2000.

5. Depkes R.I. Hasil Riset Kesehatan Dasar (RISKESDAS) 2010 Provinsi Lampung; 2010.

6. Dinas Kesehatan Lampung Tengah. Profil Kesehatan Kabupaten Lampung Tengah Tahun $2009 ; 2010$.

7. Dinas Kesehatan Lampung Timur. Profil Kesehatan Kabupaten Lampung Timur Tahun $2009 ; 2010$.

8. Dinas Kesehatan Kota Metro, Profil Kesehatan Kota Metro, 2010;2011.

9. Depkes. R.I. Asuhan Kesehatan Anak dalam Konteks Keluarga. Pusdiknakes. Jakarta ; 1993.

10. Manuaba, I.B.G., et.al. Pengantar Kuliah Obstetri. EGC, Jakarta; 1998.

11. Prawirohardjo, S. Ilmu Kebidanan. YBP-SP Jakarta; 1992.

12. Wahyuni, dkk. Hubungan Preeklampsia Berat pada Ibu Hamil terhadap Kejadian BBLR di RSUP Dr. Sardjito Yogyakarta ; 2005.

13. Kurniawati. Hubungan Pre Eklampsia dengan kelahiran Berat Bayi Lahir Rendah (BBLR) di RSUD Sragen. http://digilib.uns.ac.id/ pengguna.php?mn=detail\&d_id=15853;2010.

14. Abbas, Dessyani H. Hubungan antara preeklampsia/eklampsia dengan BBLR di RSUD dr. Moewardi Surakarta. Skripsi thesis,
Universitas $\mathrm{Muhammadiyah}$ Surakarta.http://etd.eprints.ums.ac.id/16280/ ; 2010.

15. Medical Record RSUD Jend Ahmad Yani. Laporan Ibu Bersalin tahun 2010. Kota Metro ; 2010

16. Sistiarani C, Faktor Maternal dan Kualitas Pelayanan Antenatal Yang Berisiko Terhadap Kejadian Berat Badan Lahir Rendah (BBLR) Studi Pada ibu Yang Periksa Hamil Ke Tenaga Kesehatan Dan Melahirkan Di RSUD Banyumas. http://eprints.undip.ac.id/ 16901/1/Colti Sistiarani.pdf.; 2008.

17. Lemeshow,S. et.al. Besar Sampel Dalam Penelitian Kesehatan. UGM ; 1997.

18. Cunningham, G.F., et.al. Obstetri Williams. EGC, Jakarta; 2005

19. Wiknjosastro, H. dkk. Ilmu Kebidanan. Yayasan Bina Pustaka Sarwono Prawirohardjo. Jakarta ; 2005.

20. Islamiyati, dkk. Hubungan Anemia Ibu Hamil dengan Bayi Berat Lahir Rendah Di Kabupaten Lampung Tengah Tahun 2010. Poltekkes Kemenkes Tanjungkarang;2010.

21. Apriyanti. Hubungan antara Pendidikan dan Ibu Bersalin dengan Kejadian BBLR Di RSUP Dr. Mohammad Hoesin Palembang; 2009.

22. Notoatmodjo. Pendidikan dan Perilaku Kesehatan, Penerbit Rineka Cipta, Jakarta ; 2003.

23. Widiyastuti P. Faktor-Faktor Risiko Ibu Hamil yang Berhubungan dengan Kejadian BBLR Studi Kasus di Wilayah Kerja Puskesmas Ampel I B o y o 1 a $1 \mathrm{i}$ T a h u n 20008 . http://lib.unnes.ac.id/5907/;2009.

24. Simarmata. Hubungan Kualitas Pelayanan Antenatal terhadap Kejadian Bayi Berat Lahir Rendah di Indonesia (Analisis Data Sekunder Survei Demografi Dan Kesehatan Indonesia Tahun 2007). Tesis FKM UI. Depok ; 2010. 